\title{
CUDZOZIEMIEC W URZĘDZIE ELEMENTY JEZZYKA PRAWA I ADMINISTRACJI PUBLICZNEJ W PROGRAMACH NAUCZANIA JEZYKA POLSKIEGO JAKO OBCEGO
}

\begin{abstract}
Słowa kluczowe: edukacja imigrantów, język polski jako obcy, język specjalistyczny, programy nauczania, nauczanie słownictwa, elementy języka prawa i administracji dla imigrantów, inwentarze leksykalne, teksty użytkowe

Streszczenie. W artykule przedstawiono proces tworzenia inwentarzy leksykalnych w oparciu o refleksyjne podejście do programów nauczania. Przy konsekwentnym stosowaniu zasady realizacji potrzeb komunikacyjnych i realizacji zadań językowych ,z życia wziętych” wprowadza się słownictwo specjalistyczne z dziedziny prawa i administracji publicznej do inwentarzy od poziomu A2, uwzględniając strefę życia publicznego, jak również prywatnego. Cudzoziemiec-imigrant czy cudzoziemiec-uchodźca ma czynny i bierny kontakt ze słownictwem specjalistycznym w rozmowach z pracownikami służby cywilnej, personelem placówek edukacyjnych, ale także z Polakami, z którymi utrzymuje kontakt o charakterze nieoficjalnym, prywatnym.
\end{abstract}

\section{WPROWADZENIE}

W odpowiedzi na procesy migracji ludności we współczesnej dydaktyce języków obcych coraz częściej bada się potrzeby użytkownika języka, który występuje w roli obywatela kraju, nie zaś turysty czy biznesmena w podróży służbowej. Miejsca i sytuacje jego codziennej komunikacji są bliskie rodzimym użytkownikom języka, mieszkańcom danego kraju. Imigrant, który zdecydował się osiąść w Polsce, korzysta z instytucji użytku publicznego, załatwiając procedurę legalizacji pobytu, korzystając z usług medycznych, pomocy socjalnej czy edukacji. Obcuje on na co dzień ze słownictwem z kręgów języków

*sbusilo@linguaemundi.gmail.com, Fundacja Nauki Języków Obcych „Linguae Mundi”, 02-078 Warszawa, ul. Krzywickiego 34B; Instytut Polonistyki Stosowanej Uniwersytetu Warszawskiego, 00-927 Warszawa, ul. Krakowskie Przedmieście 26/28. 
specjalistycznych. Bywa w urzędach, czyta regulaminy i informatory, wypełnia formularze.

Prawdziwym wyzwaniem dla autorów programów nauczania i materiałów dydaktycznych jest ustalenie szczegółowych wskaźników kompetencji językowej, kompetencji ogólnych, umiejętności praktycznych (savoir-faire), a wreszcie niezbędnych kompetencji socjolingwistycznych, socjokulturowych, realioznawczych, międzykulturowych, które pozwolą samodzielnie funkcjonować w społeczeństwie osobom uczestniczącym w procesach integracji.

Naukę odmian specjalistycznych języka, między innymi ze względu na stopień trudności leksyki, stopień trudności składni, stopień abstrakcji i relacji logicznych, zwykło się wprowadzać na poziomach biegłości językowej odpowiednio B1/B2, B2, C1, C2. Większość dydaktyków i teoretyków koncentruje się przede wszystkim na dwóch sferach życia: zawodowej i ewentualnie prywatnej, analizując komunikację nieoficjalną środowisk zawodowych. Uwzględniane są dwie odmiany języków specjalistycznych: teoretyczna, naukowa oraz zawodowa.

Cudzoziemiec, imigrant, uchodźca występuje w szczególnych rolach: obywatela, petenta, ewentualnie pracownika. Często korzysta z pomocy thumacza, asystenta kulturowego, wolontariusza. W urzędzie do spraw cudzoziemców wypełnia formularze dwujęzyczne, lecz inne urzędy dysponują wyłącznie wersją polskojęzyczną. Zdarza się, że imigrant znajduje się w sytuacjach, które wymagają komunikacji po polsku z wykorzystaniem specjalistycznego słownictwa, na przykład wtedy, gdy rozmawia w autobusie z kontrolerem, który przytacza fragment regulaminu korzystania ze środków transportu i poucza o konsekwencjach jazdy bez biletu, czy w czasie rozmowy z sąsiadem, nauczycielką, kolegą z pracy, gdy omawia kwestie legalizacji pobytu lub procedury otrzymania statusu uchodźcy. Dlatego układając programy nauczania imigrantów należy rozważnie wybierać zagadnienia, które znacznie zwiększą stopień samodzielności komunikacyjnej słuchaczy.

Poniższy artykuł koncentruje się na problemach kompetencji językowej, która warunkuje samodzielną komunikację obywatela - petenta i zawiera propozycję wykazu:

- zadań językowych,

- tematów zajęć (w ramach katalogu tematycznego),

- form tekstów użytkowych,

- terminologii z zakresu języka prawa i administracji oraz słownictwa typowego dla stylu urzędowo-kancelaryjnego (w ramach katalogu leksykalnego).

Niezależnie od przyjętej definicji języka specjalistycznego, ujętego w wąskim rozumieniu ograniczającym zakres do słownictwa, czy w szerszym, obejmującym także gramatykę, jak również teksty, słownictwo specjalistyczne odgrywa 
W nim istotną rolę ${ }^{1}$ W procesie komunikacji znajomość słownictwa warunkuje w znacznym stopniu wszystkie sprawności: recepcję, produkcję, interakcję i mediację. Wartość inwentarza leksykalnego służy również standaryzacji nauczania, stanowi cenny element opracowania programów, pomocy dydaktycznych i standardów egzaminacyjnych.

Prezentowany materiał przedstawia koncepcję programową, będącą wynikiem doświadczeń zebranych w latach 2006-2015 w ramach szkoleń językowych organizowanych dla imigrantów, w tym uchodźców, przez Fundację Nauki Języków Obcych „Linguae Mundi”2. Badanie potrzeb opiera się na wywiadach przeprowadzonych z imigrantami oraz pracownikami sektora służby cywilnej. Odwołuje się do obowiązujących w Polsce praw, a także praktyk funkcjonujących w urzędach obsługujących cudzoziemców w Warszawie.

Analizie warstwy leksykalnej poddano korespondencję urzędową, formularze, informatory, tablice ogłoszeń, portale informacyjne dla cudzoziemców, strony internetowe urzędów, a także podręcznik do nauki języka polskiego dla cudzoziemców Chcę pracować w Polsce pod red. M. Jasnos (Wiśniewska A. i in. 2014). Punkt odniesienia badań stanowią obwiązujące programy nauczania języka polskiego cudzoziemców opracowane przez Ministerstwo Edukacji Narodowej ${ }^{3}$, a także Programy nauczania języka polskiego jako obcego. Poziomy A1-C2 ${ }^{4}$.

Przedstawione poniżej wybrane katalogi treści programowych realizują podstawowe założenia dydaktyczne:

- biorą pod uwagę profil użytkowników języka obejmujący grupę cudzoziemców planujących stały pobyt w Polsce (imigrantów, uchodźców),

- odnoszą się przede wszystkim do poziomu nauczania A2/B1 (miejscami uwzględniono poziomy B2 oraz $\mathrm{C} 2$ ),

${ }^{1} \mathrm{~W}$ zasadzie do lat. 60. XX wieku badania nad językiem specjalistycznym koncentrują się na terminologii, por. W. Reinhardt (1969), W. Schmidt (1969); skrajną rolę słownictwu przypisuje Z. Würster (1953). T. Milewski (1975) definiuje języki specjalistyczne jako takie, które charakteryzując się głównie odrębnym słownictwem; A. Furdal (1973) uznaje właśnie słownictwo za najważniejszy aspekt stylu naukowego. W Polsce terminologią zajmowali się H. Jadacka (1976), M. Mazur (1961), M. Szymczak (1978). Teoretyczne podstawy terminologii zawdzięczamy publikacjom F. Gruczy (1991a-b), M. Jurkowskiego (1991), J. Lukszyna (1991). A. Szulc (1984) zwraca uwagę na rolę składni oraz form gramatycznych w specjalistycznych odmianach polszczyzny. Jest to zgodne z teorią stylów funkcjonalnych H. Kurkowskiej i S. Skorupki (1959), opisem odmian polszczyzny A. Wilkonia (1987) czy profesjolektów S. Grabiasa (2001). Badania nad językami specjalistycznymi z uwzględnieniem słownictwa, gramatyki, typologii gatunków i tekstów z perspektywy podejścia komunikacyjnego w nauczaniu języków obcych prowadzą m.in. S. Gajda (1982-1990b), S. Grucza (2006-20013). W tym nurcie analizują język prawa i administracji B. Wróblewski (1948) czy M. Zieliński (2004).

${ }^{2}$ Szczegółowy opis projektów przedstawia artykuł U. Sajkowskiej (2013) Nauczanie i certyfikacja specjalistycznych odmian języka polskiego jako obcego w kontekście rozwiąań europejskich i doświadczeń Fundacji Nauki Języków Obcych ,Linguae Mundi”.

${ }^{3}$ Ramowy program kursów nauki języka polskiego dla cudzoziemców (2011), Rozporządzenie Ministra Edukacji Narodowej z dnia 18 lutego 2011 r.

${ }^{4}$ Programy nauczania języka polskiego jako obcego. Poziomy A1-C2 (2011), red. W. Miodunka, Kraków. 
- obejmują sferę publiczną (w tym zawodową) oraz prywatną,

- wyodrębniają treści nauczania uwzględniające realne potrzeby realizacji działań społecznych w życiu codziennym.

\section{OPIS KONCEPCJI PROGRAMU}

\subsection{ZAŁOŻENIA}

Ramowy program kursów nauki języka polskiego dla cudzoziemców Ministerstwa Edukacji Narodowej ${ }^{5}$ jako podstawowy cel kształcenia wskazuje sprawność komunikacyjną w sytuacjach związanych z realizację procedur urzędowych: „Za podstawowe cele kształcenia należy uznać: komunikowanie się w języku polskim w podstawowych sytuacjach codziennych związanych z organizacją życia w Polsce, podróżowaniem, załatwianiem spraw urzędowych”.

Programy nauczania języka polskiego jako obcego (2011), dostosowane do ram Europejskiego Systemu Opisu Kształcenia Językowego, na poziomie B1 zakładają samodzielność komunikacyjną w sytuacjach życia codziennego związanych z wynajmowaniem mieszkania, poruszaniem się po placówkach służby zdrowia czy załatwianiem spraw urzędowych ${ }^{6}$. Zgodnie z przedstawionym założeniem, ważne są dwie kategorie w ocenie treści programowych: częstotliwość występowania w codziennej komunikacji i prawdopodobieństwo zaistnienia danej sytuacji komunikacyjnej w życiu cudzoziemca-imigranta.

Strefa życia publicznego związana $\mathrm{z}$ procedurami urzędowymi została uwzględniona $\mathrm{w}$ obu programach, które wprowadzają ten temat $\mathrm{w}$ zasadzie od poziomu A2. Analizowane treści obecne są w katalogu tematycznym, funkcjonalno-pojęciowym, realioznawczym, socjokulturowym, łączą się z uwzględnionymi rolami komunikacyjnymi. Różnią się stopniem realizacji poszczególnych zagadnień, a także poziomami do nich przypisanymi, co zostanie szerzej omówione w dalszej części artykułu. Autorka pracy spróbuje także odpowiedzieć na pytanie, czy realizacja potrzeb językowych wymaga wprowadzenia słownictwa specjalistycznego z zakresu prawa i administracji, w tym języka aktów prawnych, decyzji administracyjnych, umów cywilno-prawnych, korespondencji urzędowej, a także języka uczestników aktów komunikacyjnych związanych z realizacją procedur urzędowych z uwzględnieniem kontekstu komunikacji.

Niestety żaden z programów nie obejmuje inwentarza słów ani przykładowych fraz, co byłoby niezmiernie pomocne w utrzymaniu jednego standardu uczenia (się), tworzeniu materiałów dydaktycznych, standardów egzaminacyjnych.

${ }^{5}$ Ramowy program kursów nauki języka polskiego dla cudzoziemców (2011), Rozporządzenie Ministra Edukacji Narodowej z dnia 18 lutego 2011 r., (poz. 306), pkt. 2.1.

${ }^{6}$ Por. Europejski System Opisu Kształcenia Językowego, pkt. 4.2.2. 


\subsection{KONTEKST KOMUNIKACJI}

By opracować zawartość katalogu tematycznego, listę sytuacji komunikacyjnych, zadań językowych, tekstów użytkowych, które cudzoziemiec powinien znać, dobrze jest odnieść się w pierwszej kolejności do kategorii budujących kontekst komunikacji, tj. kategorii miejsca, instytucji, osób, przedmiotów, zdarzeń, czynności i tekstów?

Tabela 1. Zewnętrzny kontekst komunikacji językowej imigrantów

\begin{tabular}{|c|c|c|c|c|c|c|}
\hline Miejsca & Instytucje & Osoby & Przedmioty & Zdarzenia & i czynności & Teksty \\
\hline $\begin{array}{l}\text { biletomat, } \\
\text { ośrodek } \\
\text { recepcyjny, } \\
\text { stanowisko } \\
\text { obsługi } \\
\text { klienta, } \\
\text { środki } \\
\text { transportu, } \\
\text { ulica, } \\
\text { plac, } \\
\text { parking, } \\
\text { itp. }\end{array}$ & $\begin{array}{l}\text { organizacje } \\
\text { pozarządowe, } \\
\text { poczta, } \\
\text { policja, } \\
\text { sąd, } \\
\text { straż miejska, } \\
\text { urząd ds. } \\
\text { cudzoziem- } \\
\text { ców, } \\
\text { urząd gminy, } \\
\text { urząd pracy, } \\
\text { urząd skar- } \\
\text { bowy, } \\
\text { urząd stanu } \\
\text { cywilnego, } \\
\text { itp. }\end{array}$ & $\begin{array}{l}\text { adwokat, } \\
\text { asystent } \\
\text { kulturowy, } \\
\text { imigrant, } \\
\text { uchodźca, } \\
\text { cudzozie- } \\
\text { miec, } \\
\text { kontroler, } \\
\text { konduktor, } \\
\text { klient, } \\
\text { naczelnik, } \\
\text { petent, } \\
\text { pracownik } \\
\text { ochrony, } \\
\text { recepcjonist- } \\
\text { ka, } \\
\text { referent, } \\
\text { specjalista, } \\
\text { świadek, } \\
\text { tłumacz, } \\
\text { urzędnik, } \\
\text { wolontariusz, } \\
\text { itp. }\end{array}$ & $\begin{array}{l}\text { bilet, } \\
\text { dokumenty } \\
\text { tożsamości } \\
\text { (paszport, } \\
\text { karta pobytu, } \\
\text { TZTC, itp.), } \\
\text { dowody } \\
\text { w sprawie, } \\
\text { formularz, } \\
\text { identyfikator, } \\
\text { materiały } \\
\text { piśmiennicze, } \\
\text { numerek, } \\
\text { pieczątka, } \\
\text { pieniądze, } \\
\text { talon, } \\
\text { znaczki, } \\
\text { itp. }\end{array}$ & $\begin{array}{l}\text { aplikacja, } \\
\text { areszt, } \\
\text { deportacja, } \\
\text { grzywna, } \\
\text { legalizacja, } \\
\text { pobytu, } \\
\text { mandat, } \\
\text { nostryfikacja, } \\
\text { nadanie oby- } \\
\text { watelstwa, } \\
\text { nadanie statu- } \\
\text { su uchodźcy, } \\
\text { pobieranie } \\
\text { odcisków } \\
\text { palców, } \\
\text { postępowania } \\
\text { i procedury } \\
\text { urzędowe: } \\
\text { wszczęcie po- } \\
\text { stępowania, } \\
\text { umorzenie } \\
\text { postępowa- } \\
\text { nia, }\end{array}$ & $\begin{array}{l}\text { urzędowe } \\
\text { procesy } \\
\text { sądowe, } \\
\text { pobieranie } \\
\text { numerka, } \\
\text { rejestracja } \\
\text { pojazdu, } \\
\text { uzyskanie } \\
\text { pomocy } \\
\text { socjalnej, } \\
\text { wymiana do- } \\
\text { kumentów, } \\
\text { zaproszenie } \\
\text { cudzoziemca, } \\
\text { wizyta } \\
\text { w urzędzie, } \\
\text { wywiad, } \\
\text { przesłucha- } \\
\text { nie, } \\
\text { zatrzymanie, } \\
\text { itp. }\end{array}$ & $\begin{array}{l}\text { awizo, } \\
\text { decyzja, } \\
\text { druki pocz- } \\
\text { towe, } \\
\text { formularz, } \\
\text { list oficjalny, } \\
\text { materiały in- } \\
\text { formacyjne, } \\
\text { obwieszcze- } \\
\text { nie, } \\
\text { odmowa, } \\
\text { odwołanie, } \\
\text { ogłoszenie, } \\
\text { podanie, } \\
\text { protokół, } \\
\text { przepisy, wy- } \\
\text { ciągi, skróty, } \\
\text { regulamin, } \\
\text { rozporządze- } \\
\text { nie, } \\
\text { ustawa, } \\
\text { wezwanie, } \\
\text { wniosek, } \\
\text { zaświadcze- } \\
\text { nie, } \\
\text { zawiadomie- } \\
\text { nie, } \\
\text { itp. }\end{array}$ \\
\hline
\end{tabular}

Źródło: opracowanie własne

${ }^{7}$ Por. Europejski System Opisu Kształcenia Językowego, pkt. 4.1.2. 
Jak widać w przedstawionej tabeli (Tabela 1) zebrano konteksty, które mogą, ale nie muszą, dotyczyć każdego cudzoziemca. Do ośrodka recepcyjnego trafiają tylko uchodźcy, to oni powinni wiedzieć, co to jest TZTC (tymczasowe zaświadczenie tożsamości cudzoziemca). Używają oni tego terminu na co dzień, podobnie jak talonów żywieniowych czy identyfikatorów. Natomiast imigranci niebędący uchodźcami legitymują się kartą pobytu, nie dotyczy ich procedura nadania statusu uchodźcy, lecz uzyskania zgody na pobyt tolerowany, nadanie obywatelstwa.

\subsection{KATALOG ZADAŃ JĘZYKOWYCH I REALIOZNAWSTWO}

O sprawności komunikacyjnej można mówić, gdy użytkownik języka jest w stanie podejmować działania językowe, rozumieć i tworzyć teksty, jak również realizować zadania językowe, wymagające kompetencji ogólnych, umiejętności technicznych związanych z obsługą komputera, urządzeń elektronicznych, biletomatów, bankomatów, znajomością zasad korzystania z komunikacji miejskiej, usług, znajomością praw konsumenta, ściśle powiązanych z rozwiązywaniem konkretnego problemu lub osiągnięciem jakiegoś celu w życiu codziennym ${ }^{8}$. W przypadku imigranta będzie to na przykład legalizacja własnego pobytu, wymiana dokumentu tożsamości, odebranie świadczeń pieniężnych przewidzianych dla uchodźców, znalezienie pracy, wynajęcie mieszkania, itp. Poniższa propozycja katalogu zawiera spis podstawowych zadań, który należy uzupełniać i modyfikować w zależności od indywidualnych potrzeb użytkowników.

Katalog zadań językowych wymagających znajomości elementów języka prawa i administracji

Cudzoziemiec potrafi:

- znaleźć potrzebne informacje na stronach internetowych urzędu,

- podjąć odpowiednie kroki związane z procedurą legalizacji pobytu,

- korzystać z ofert urzędu pracy,

- korzystać z przysługującej pomocy socjalnej,

- korzystać z pomocy organizacji pozarządowych,

- korzystać z oferty placówek edukacyjnych,

- wymienić dokument tożsamości,

- wyrobić numer NIP, PESEL,

- zarejestrować się jako bezrobotny,

- negocjować warunki najmu mieszkania oraz treść umowy,

- negocjować warunki pracy oraz treść umowy,

- wymienić prawo jazdy,

${ }^{8}$ Por. Europejski System Opisu Ksztatcenia Językowego, pkt. 2.1 oraz Janowska (2011), s. 171-175. 
- nostryfikować dyplom,

- odebrać akt urodzenia dziecka,

- zarejestrować pojazd,

- otworzyć działalność gospodarczą,

- zapisać dziecko do przedszkola, do szkoły.

Do realizacji powyższych zadań potrzebna jest podstawowa wiedza z zakresu działań służby cywilnej, tj. administracji państwowej oraz sektora pozarządowego, a także podstawowa wiedza dotycząca podziału administracyjnego Polski. Cudzoziemiec powinien znać: nazwę własnego województwa, powiatu czy dzielnicy, w której mieszka, a ponadto: typy dokumentów tożsamości oraz sposoby identyfikacji osobowej i podatkowej (NIP I PESEL), środki płatnicze w Polsce i sposoby płatności czy zasady korzystania ze środków komunikacji miejskiej. Znajomość realiów kraju pobytu cudzoziemca warunkuje jego skuteczność komunikacyjną. W przypadku imigranta ważna jest znajomość wybranych zagadnień prawnych, w tym z zakresu: prawa międzynarodowego odnoszącego się do polityki migracyjnej oraz prawa cywilnego, administracyjnego i karnego związanego z pracą, najmem mieszkania, usługami, transportem i komunikacją publiczną, opieką nad dzieckiem, narodzinami, ślubem, pogrzebem, rejestracją pojazdów, meldunkiem, rejestracją działalności gospodarczej itp.

Pochodną kontekstu komunikacji są role komunikacyjne, w których występuje użytkownik języka. Poniżej przedstawiono propozycję zmian katalogu zawartego w Programach nauczania języka polskiego jako obcego. Poziomy A1-C2. (2011)

Tabela 2. Role komunikacyjne

\begin{tabular}{|c|c|c|c|}
\hline & A2 & B1 & B2 \\
\hline 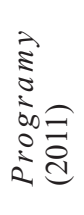 & $\begin{array}{l}\text { wynajmujący } \\
\text { mieszkanie }\end{array}$ & $\begin{array}{l}\text { Pracodawca } \\
\text { pracownik } \\
\text { urzędnik } \\
\text { petent } \\
\text { pasażer }\end{array}$ & $\begin{array}{l}\text { kierowca } \\
\text { właściciel pojazdu } \\
\text { uczestnik wypadku drogo- } \\
\text { wego } \\
\text { ofiara przestępstwa } \\
\text { świadek }\end{array}$ \\
\hline 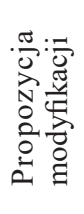 & $\begin{array}{l}\text { pracownik } \\
\text { petent } \\
\text { pasażer } \\
\text { ofiara przestępstwa } \\
\text { mieszkaniec ośrodka recep- } \\
\text { cyjnego }\end{array}$ & $\begin{array}{l}\text { uczestnik wypadku drogo- } \\
\text { wego } \\
\text { kierowca } \\
\text { właściciel } \\
\text { świadek }\end{array}$ & \\
\hline
\end{tabular}

Źródło: opracowanie własne 


\subsection{KATALOG TEMATYCZNY}

Analizując w programie MEN listę zagadnień tematycznych, obejmujących słownictwo o charakterze specjalistycznym z dziedziny prawa i administracji, charakterystyczne dla stylu urzędowo-kancelaryjnego, można wskazać następującą listę tematów przypisanych do poszczególnych poziomów, rzadko powracających na wyższych poziomach:

- w obszarze Nauka, kultura i styl życia, wymienia się urzędy administracji publicznej już na poziomie A2 oraz pomoc społeczną na poziomie B2,

- w obszarze Praca, warunki pracy oraz płacy pojawiają się już na poziomie A1 i są stopniowo rozwijane,

- w obszarze Mieszkanie słownictwo związane z kosztami występuje już na poziomie $\mathrm{A} 1$, na poziomie $\mathrm{B} 2$ pojawiają się rodzaje własności oraz wynajem,

- w obszarze Zdrowie, do poziomu A1 przypisane zostały ubezpieczenia,

- w obszarze Życie codzienne na poziomie A1 występuje poczta i policja, na poziomie $\mathrm{A} 2$ bank $^{9}$.

W programie MEN tematy takie, jak ekonomia, gospodarka, finanse, nauka i technika czy prawo, zostały uwzględnione w stopniu niedostatecznym lub nie zostały uwzględnione w ogóle. Tematy związane z wynajmem mieszkania, kwalifikacjami zawodowymi, silnie obecne w codziennej komunikacji cudzoziemców-imigrantów, pojawiają się dopiero na poziomie B2.

Dobrym punktem odniesienia w toku analizy zagadnień tematycznych może być propozycja treści przedstawionych w Programach nauczania języka polskiego jako obcego (2011). Poniżej przedstawiono autorską propozycję rozszerzenia i uszczegółowienia niektórych obszarów tematycznych z uwzględnieniem poziomów B2 i C2.

Tabela 3. Katalog tematyczny

\begin{tabular}{|l|l|}
\hline $\begin{array}{l}\text { Wykaz tematyczny w Programach nauczania } \\
\text { języka polskiego jako obcego. Poziomy A1-C2. }\end{array}$ & \multicolumn{1}{|c|}{$\begin{array}{c}\text { Program nauczania języka polskiego } \\
\text { dla imigrantów }\end{array}$} \\
\hline $\begin{array}{l}\text { Czlowiek } \\
\text { dane osobowe: imię i nazwisko, imię matki, imię } \\
\text { ojca, adres, płeć, wiek, data i miejsce urodzenia, } \\
\text { stan cywilny, wykształcenie, obywatelstwo, naro- } \\
\text { dowość, zawód, }\end{array}$ & $\begin{array}{l}\text { Człowiek } \\
\text { dane osobowe: imię i nazwisko, nazwisko rodowe, } \\
\text { wygląd zewnętrzny, } \\
\text { rodzina, członkowie rodziny } \\
\text { sce urodzenia, miejscowość, kraj, stan cywilny, wy- } \\
\text { kształcenie, obywatelstwo, narodowość, zawód, za- } \\
\text { wód wyuczony, zawód wykonywany, wyznanie *** } \\
\text { wygląd zewnętrzny, rysopis, znaki szczególne } \\
\text { rodzina, członkowie rodziny } \\
\text { pracownicy służby cywilnej, pracownicy służb } \\
\text { mundurowych } \\
\text { dokumenty tożsamości }\end{array}$ \\
\hline
\end{tabular}

\footnotetext{
${ }^{9}$ Ramowy program kursów nauki języka polskiego dla cudzoziemców, pkt. 7.
} 


\begin{tabular}{|c|c|}
\hline $\begin{array}{l}\text { Miejsca } \\
\text { miasto, wieś, miejscowość } \\
\text { plan przestrzenny, zabudowania miejskie } \\
\text { struktura budynku (korytarz, winda, schody, piętro, } \\
\text { pokój, stanowisko) } \\
\text { instytucje użytku publicznego }\end{array}$ & $\begin{array}{l}\text { Miejsca } \\
\text { miasto, wieś, miejscowość } \\
\text { plan przestrzenny, zabudowania miejskie } \\
\text { struktura budynku (korytarz, winda, schody, piętro, } \\
\text { pokój, stanowisko) } \\
\text { instytucje użytku publicznego } \\
\text { urzędy, urząd ds. cudzoziemców, urząd skarbowy, } \\
\text { urząd gminy, centrum pomocy rodzinie, urząd pra- } \\
\text { cy, urząd stanu cywilnego } \\
\text { sądy (**) } \\
\text { organizacje pozarządowe, stowarzyszenia, ośrodki } \\
\text { pomocy społecznej } \\
\text { ośrodek recepcyjny }\end{array}$ \\
\hline $\begin{array}{l}\text { Podróże i środki transportu } \\
\text { środki komunikacji miejskiej }\end{array}$ & $\begin{array}{l}\text { Podróże i środki transportu } \\
\text { środki komunikacji miejskiej }\end{array}$ \\
\hline $\begin{array}{l}\text { Praca } \\
\text { miejsca pracy } \\
\text { nazwy zawodów } \\
\text { rynek pracy, warunki pracy, warunki zatrudnienia } \\
\text { (kwalifikacje**, wymagania**), rodzaje umów, } \\
\text { prawo pracy** (warunki pracy, czas pracy, urlop*, } \\
\text { renty***, emerytury***, zasiłki***) } \\
\text { proces poszukiwania pracy i aplikacji }\end{array}$ & $\begin{array}{l}\text { Praca } \\
\text { miejsca pracy } \\
\text { nazwy zawodów } \\
\text { rynek pracy, warunki pracy, warunki zatrudnienia } \\
(\text { kwalifikacje*, wymagania*), rodzaje umów, } \\
\text { prawo pracy** (warunki pracy, czas pracy, urlop*, } \\
\text { renty*, emerytury*, zasiłki*) } \\
\text { przepisy BHP, proces poszukiwania pracy i aplikacji }\end{array}$ \\
\hline $\begin{array}{l}\text { Państwo i spoleczeństwo * } \\
\text { organizacja państwa* } \\
\text { uroczystości państwowe* } \\
\text { sytuacja polityczna i gospodarcza* } \\
\text { organy ścigania *** } \\
\text { podstawowe organizacje międzynarodowe *** } \\
\text { najważniejsze polskie partie polityczne } \\
\text { warunki życia* } \\
\text { przestępczość }\end{array}$ & $\begin{array}{l}\text { Państwo i spoleczeństwo * } \\
\text { organizacja państwa* } \\
\text { uroczystości państwowe } \\
\text { sytuacja polityczna i gospodarcza* } \\
\text { organy ścigania } \\
\text { podstawowe organizacje międzynarodowe } \\
\text { najważniejsze polskie partie polityczne } \\
\text { warunki życia } \\
\text { przestępczość* } \\
\text { cudzoziemcy - prawa i obowiązki } \\
\text { pomoc społeczna }\end{array}$ \\
\hline $\begin{array}{l}\text { Mieszkanie } \\
\text { wynajmowanie }\end{array}$ & $\begin{array}{l}\text { Mieszkanie } \\
\text { rodzaje własności** } \\
\text { wynajmowanie } \\
\text { umowa }\end{array}$ \\
\hline
\end{tabular}




\subsection{TEKSTY UŻYTKOWE}

W programie MEN, w katalogu tekstów, które cudzoziemiec powinien rozumieć lub redagować, uwzględniono komunikaty w miejscach publicznych, ogłoszenia, rozkłady jazdy, formularze i pisma urzędowe, w tym podanie, zawiadomienie, a także życiorys, list motywacyjny, skargę, reklamację, protest, odwołanie od decyzji ${ }^{10}$.

Tabela 4. Wykaz form pisemnych oraz tekstów w programie MEN

\begin{tabular}{|l|c|l|c|}
\hline \multicolumn{1}{|c|}{ Pisanie } & Poziom & \multicolumn{1}{|c|}{ Rozumienie tekstów } & Poziom \\
\hline formularz danych osobowych & A1 & ogłoszenia, rozkłady jazdy, instrukcje & A2 \\
\hline $\begin{array}{l}\text { proste pisma oficjalne urzędowe, } \\
\text { podanie i życiorys }\end{array}$ & A2 & oficjalne pisma urzędowe & A2 \\
\hline zawiadomienie i list motywacyjny & B1 & $\begin{array}{l}\text { korespondencja prywatna opisująca } \\
\text { wydarzenia i uczucia* }\end{array}$ & B1 \\
\hline $\begin{array}{l}\text { ogłoszenie, skarga, reklamacja, } \\
\text { protest, odwołanie od decyzji }\end{array}$ & B2 & artykuły, reportaże, proza literacka* & B2 \\
\hline
\end{tabular}

Źródło: Program MEN (2011)

Spośród krótkich pism urzędowych wymienia się zawiadomienie, nie wskazuje się wniosku, podania, decyzji, upoważnienia, wyciągów z regulaminów, broszur informacyjnych, z którymi cudzoziemcy mają częsty kontakt. Propozycja przedstawiona w Programach (2011) jest pełniejsza, choć również wydaje się warta uzupełnienia.

Tabela 5. Katalog tekstów użytkowych

\begin{tabular}{|c|c|c|}
\hline & $\begin{array}{l}\text { Wykaz tekstów użytkowych } \\
\text { w Programach nauczania języka polskiego } \\
\text { jako obcego. Poziomy A1-C2. }\end{array}$ & $\begin{array}{c}\text { Program nauczania języka polskiego } \\
\text { dla imigrantów } \\
\text { (autorska propozycja modyfikacji) }\end{array}$ \\
\hline & $\begin{array}{l}\text { list motywacyjny } \\
\text { odwołanie od decyzji } \\
\text { podanie } \\
\text { podstawowa forma podania } \\
\text { podstawowa forma życiorysu } \\
\text { podstawowe formy listu oficjalnego } \\
\text { reklamacja } \\
\text { skarga } \\
\text { życiorys }\end{array}$ & $\begin{array}{l}\text { list motywacyjny } \\
\text { odwołanie od decyzji } \\
\text { oświadczenie } \\
\text { podanie } \\
\text { podstawowa forma podania } \\
\text { podstawowa forma życiorysu } \\
\text { podstawowe formy listu oficjalnego } \\
\text { reklamacja } \\
\text { skarga } \\
\text { upoważnienie } \\
\text { zaświadczenie } \\
\text { życiorys }\end{array}$ \\
\hline
\end{tabular}

${ }^{10}$ Tamże, pkt. 5. 


\begin{tabular}{|c|c|c|}
\hline & $\begin{array}{c}\text { Wykaz tekstów użytkowych } \\
\text { w Programach nauczania języka polskiego } \\
\text { jako obcego. Poziomy A1-C2. }\end{array}$ & $\begin{array}{c}\text { Program nauczania języka polskiego } \\
\text { dla imigrantów } \\
\text { (autorska propozycja modyfikacji) }\end{array}$ \\
\hline 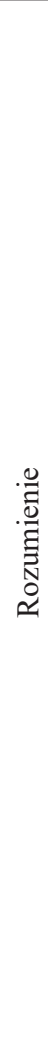 & $\begin{array}{l}\text { formularze urzędowe } \\
\text { komunikaty w miejscach publicznych } \\
\text { nakazy, zakazy, ostrzeżenia } \\
\text { pisma urzędowe } \\
\text { umowa najmu } \\
\text { umowa o pracę } \\
\text { zawiadomienia } \\
\text { list motywacyjny } \\
\text { odwołanie od decyzji } \\
\text { podanie } \\
\text { podstawowa forma podania } \\
\text { podstawowa forma życiorysu } \\
\text { podstawowe formy listu oficjalnego } \\
\text { reklamacja } \\
\text { skarga } \\
\text { umowa najmu } \\
\text { życiorys }\end{array}$ & $\begin{array}{l}\text { broszury informacyjne } \\
\text { formularze urzędowe } \\
\text { komunikaty w miejscach publicznych } \\
\text { nakazy, zakazy, ostrzeżenia } \\
\text { pisma urzędowe } \\
\text { portale dla cudzoziemców, forum } \\
\text { regulaminy } \\
\text { teksty ustaw (fakultatywnie) } \\
\text { umowa najmu } \\
\text { umowa o pracę } \\
\text { wyciągi z regulaminów } \\
\text { zawiadomienia } \\
\text { list motywacyjny } \\
\text { odwołanie od decyzji } \\
\text { oświadczenie } \\
\text { podanie } \\
\text { podstawowa forma podania } \\
\text { podstawowa forma życiorysu } \\
\text { podstawowe formy listu oficjalnego } \\
\text { reklamacja } \\
\text { skarga } \\
\text { umowa najmu } \\
\text { upoważnienie } \\
\text { zaświadczenie } \\
\text { życiorys }\end{array}$ \\
\hline
\end{tabular}

Źródło: opracowanie własne

Obecność poszczególnych tekstów użytkowych stosownie do poziomów zaawansowania językowego zależy od potrzeb językowych użytkowników, jednak postuluje się wprowadzanie już od poziomu A2 w miarę możliwości szerokiego wachlarza tekstów, ze wskazaniem na umiejętność rozpoznania funkcji tekstów, rozumienia globalnego, w tym intencji tekstu, głównych informacji, a także zgodnego z postulatem spiralnego układu treści, powracania do tekstów o bardziej rozbudowanej strukturze, trudniejszej leksyce i dłuższej formie na wyższych poziomach. 
Tabela 6. Katalog tekstów użytkowych przypisanych do poziomów językowych

\begin{tabular}{|c|c|c|c|}
\hline & A2/B1 & B1/B2 & $\mathrm{C2}$ \\
\hline 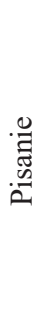 & $\begin{array}{l}\text { podstawowe formy listu } \\
\text { oficjalnego } \\
\text { podstawowa forma podania } \\
\text { podstawowa forma życio- } \\
\text { rysu } \\
\text { upoważnienie } \\
\text { oświadczenie } \\
\text { zaświadczenie }\end{array}$ & $\begin{array}{l}\text { skarga } \\
\text { reklamacja } \\
\text { odwołanie od decyzji } \\
\text { życiorys } \\
\text { podanie } \\
\text { list motywacyjny }\end{array}$ & pisma urzędowe \\
\hline 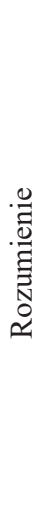 & $\begin{array}{l}\text { komunikaty w miejscach } \\
\text { publicznych } \\
\text { nakazy, zakazy, ostrzeżenia } \\
\text { formularze urzędowe } \\
\text { zawiadomienia } \\
\text { broszury informacyjne } \\
\text { wyciągi z regulaminów } \\
\text { portale dla cudzoziemców, } \\
\text { forum } \\
\text { podstawowa forma umowy } \\
\text { o pracę } \\
\text { podstawowa forma umowy } \\
\text { najmu }\end{array}$ & $\begin{array}{l}\text { formularze urzędowe } \\
\text { zawiadomienia } \\
\text { nakazy, zakazy, ostrzeżenia } \\
\text { regulaminy } \\
\text { instrukcje }\end{array}$ & $\begin{array}{l}\text { pisma urzędowe } \\
\text { teksty ustaw } \\
\text { regulaminy }\end{array}$ \\
\hline
\end{tabular}

Źródło: opracowanie własne

\subsection{INWENTARZ LEKSYKALNY}

Opracowanie listy zadań językowych, katalogu tematycznego oraz katalogu tekstów użytkowych, analiza materiałów autentycznych, korespondencji skierowanej do imigrantów, komunikatów w miejscach publicznych, publikacji o charakterze informatorów, stron internetowych urzędów oraz organizacji pozarządowych, przy uwzględnieniu ról komunikacyjnych, w których występują cudzoziemcy zarówno w sferze publicznej (w tym zawodowej), jak i prywatnej, pozwoliło wyłonić listę terminów z zakresu języka prawa i administracji, a także słownictwa typowego dla stylu urzędowo-kancelaryjnego, wspierających skuteczną, sprawną i stosowną komunikację językową cudzoziemca-imigranta w życiu codziennym związanym z załatwianiem spraw urzędowych. 


\subsubsection{Język prawa i administracji, terminologia prawnicza}

\begin{tabular}{|c|c|}
\hline $\begin{array}{l}\text { Terminy prawne o charakterze uniwersalnym } \\
\text { dokumenty prawne: } \\
\text { artykuł } \\
\text { paragraf } \\
\text { przepis } \\
\text { regulamin } \\
\text { umowa } \\
\text { ustawa } \\
\text { Osoby i podmioty działań prawnych } \\
\text { adwokat } \\
\text { podejrzany } \\
\text { przedstawiciel, pełnomocnik } \\
\text { skazany } \\
\text { strona w sprawie } \\
\text { organy władzy i administracji publicznej } \\
\text { centrum pomocy rodzinie } \\
\text { komisarz narodów zjednoczonych } \\
\text { notariusz } \\
\text { sąd } \\
\text { starosta } \\
\text { urząd ds. cudzoziemców } \\
\text { urząd gminy } \\
\text { urzad skarbowy } \\
\text { wojewoda }\end{array}$ & $\begin{array}{l}\text { Czynności prawne, akty prawne, zdarzenia } \\
\text { decyzja } \\
\text { decyzja o nadaniu statusu uchodźcy } \\
\text { decyzja o odmowie nadania statusu uchodźcy } \\
\text { decyzja o odmowie nadania statusu uchodźcy } \\
\text { i udzieleniu ochrony uzupełniającej } \\
\text { deportacja } \\
\text { kara, mandat } \\
\text { nakazy, zakazy, obowiązki } \\
\text { odmowa } \\
\text { odroczenie } \\
\text { odwołanie od decyzji } \\
\text { oświadczenie } \\
\text { postanowienie } \\
\text { postępowanie } \\
\text { procedura } \\
\text { przedawnienie sprawy } \\
\text { przekroczenie terminu } \\
\text { przesłuchanie } \\
\text { termin rozpatrzenia sprawy } \\
\text { umorzenie postępowania } \\
\text { wnioskowanie } \\
\text { wyrok } \\
\text { wywiad } \\
\text { zameldowanie } \\
\text { zeznanie } \\
\text { zezwolenie }\end{array}$ \\
\hline
\end{tabular}

\section{Legalizacja pobytu}

azyl

ochrona międzynarodowa

ochrona uzupełniająca

pobyt tolerowany

status uchodźcy

zgoda na osiedlenie się karta pobytu

tymczasowe zaświadczenie

tożsamości cudzoziemca

(TZTC)

genewski dokument podróży

protokół przesłuchania

ośrodek recepcyjny

uznanie rodzicielstwa 


\section{Prawo pomocy socjalnej}

świadczenia pieniężne

świadczenia rodzinne

dodatek z tytułu rozpoczęcia roku szkolnego

dodatek z tytułu urodzenia dziecka

zasiłek dla kobiet w ciąży i wychowujących

dziecko

zasiłek dla rodzin wielodzietnych

ekwiwalent

przyznanie dofinansowania

refundowany

zasiłek

renta

składka na ubezpieczenie zdrowotne

specjalistyczne

poradnictwo socjalne

kwota

dochody

źródła dochodów

\section{Prawo cywilne, prawo pracy}

najemca

najmujący

rozwiązanie umowy

ubezpieczenie

umowa kupna

umowa najmu

umowa o dzieło

umowa o pracę

umowa sprzedaży

umowa zlecenie

właściciel

wypowiedzenie umowy

Źródło: opracowanie własne

\subsubsection{Styl urzędowo-kancelaryjny}

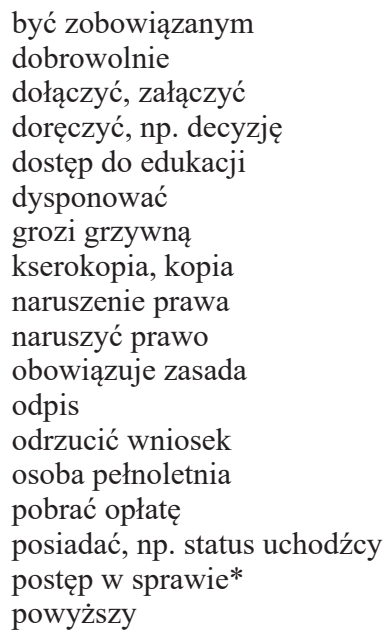

stracić świadczenia

termin ulega skróceniu/ wydłużeniu

ubiegać się o ochronę międzynarodową

udzielić ochrony

udzielić odpowiedzi

udzielić pełnomocnictwa

uiścić opłatę

uregulować mandat

uznanie

uzyskać informacje

w celu

w uzasadnionych przypadkach

w zakresie

wartościowe przedmioty

wezwać

wnieść skargę

wskazane jest

wskazany 


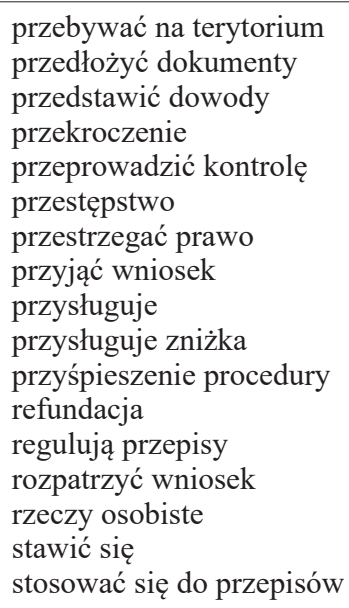

wszcząć postępowanie

wydać decyzję

wylegitymować

wystawić zaświadczenie

zakwalifikować

zaleca się

załącznik

zaniechać

zastosować się do decyzji

zataić informacje

zgłosić się

złożyć wniosek

złożyć wyjaśnienia

zrezygnować

zwlekać *

zwrot poniesionych kosztów

Źródło: opracowanie własne

\section{PODSUMOWANIE}

W artykule przedstawiono proces tworzenia inwentarzy leksykalnych w oparciu o refleksyjne podejście do programów nauczania, jak też rezultat tego procesu. Konsekwentne stosowanie zasady realizacji potrzeb komunikacyjnych i realizacji zadań językowych ,z życia wziętych” wprowadza słownictwo specjalistyczne do inwentarzy od poziomu A2, zarówno w strefę życia publicznego, jak również prywatnego. Cudzoziemiec-imigrant czy cudzoziemiec-uchodźca ma czynny i bierny kontakt ze słownictwem specjalistycznym w rozmowach z pracownikami służby cywilnej, personelem placówek edukacyjnych, ale także z Polakami, z którymi utrzymuje kontakt o charakterze nieoficjalnym, prywatnym. Wprowadzenie nazw podstawowych dokumentów prawnych, podstawowych instytucji i procedur, z którymi mają do czynienia imigranci w toku zajęć jest zadaniem możliwym do wykonania. Kręgi tematyczne i leksykalne można stopniowo rozszerzać. Gdy zajdzie taka potrzeba, być może warto kosztem zajęć o podróżowaniu, rezerwacji hotelu, zainteresowaniach, realizować program związany z załatwianiem spraw urzędowych, szczególnie tych mających charakter zdarzeń cyklicznych. Przedstawione tutaj postulaty powinny znaleźć odzwierciedlenie również w podręcznikach do nauczania języka polskiego jako obcego i standardach egzaminów skierowanych do cudzoziemców. 


\section{BIBLIOGRAFIA}

Europejski system opisu kształcenia językowego: uczenie się, nauczanie, ocenianie, 2001, Rada Europy, Strasburg.

Gajda S., 1982, Podstawy badań stylistycznych nad językiem naukowym, Wrocław.

Gajda S., 1990a, Wprowadzenie do teorii terminu, Opole.

Gajda S., 1990b, Wspótczesna polszczyzna naukowa. Język czy żargon, Opole.

Grucza F., 1985, Pierwsze dziesięciolecie Instytutu Lingwistyki Stosowanej Uniwersytetu Warszawskiego, w: F. Grucza (red.), Lingwistyka, glottodydaktyka, translatoryka, Warszawa, s. 9-17.

Grucza F., 1991a, Terminologia-jej przedmiot, status i znaczenie, w: F. Grucza (red.), Teoretyczne podstawy terminologii, Wrocław, s. 11-43.

Grucza S., 2013, Lingwistyka języków specjalistycznych, Warszawa.

Janowska I., 2011, Podejście zadaniowe do nauczania i uczenia się języków obcych.

Programy nauczania języka polskiego jako obcego. Poziomy A1-C2, 2011, W. Miodunka (red.), Kraków.

Ramowy program kursów nauki języka polskiego dla cudzoziemców, Rozporządzenie Ministra Edukacji Narodowej z dnia 18 lutego 2011 r. dot. nauczania JPJO cudzoziemców (Dz.U. 61, poz. 306).

Lukszyn J., 1991, Lingwistyczne problemy badań terminologicznych, w: F. Grucza (red.), Teoretyczne podstawy terminologii, Wrocław, s. 79-96.

Mazur M., 1961, Terminologia techniczna, Warszawa.

Szymczak M., 1978, Rola i miejsce terminologii w języku ogólnonarodowym, w: „Zagadnienia Naukoznawstwa" 4, s. 513-521.

Sajkowska U., 2013, Nauczanie i certyfikacja specjalistycznych odmian języka polskiego jako obcego w kontekście rozwiazań europejskich i doświadczeń Fundacji Nauki Języków Obcych „Linguae Mundi”, w: J. Mazur, K. Sobstyl, A. Małyska (red.), Glottodydaktyka polonistyczna w obliczu dynamiki zmian językowo-kulturowych i potrzeb społecznych, Lublin.

Wilkoń A., 1987, Typologia odmian językowych wspótczesnej polszczyzny, Katowice.

Wiśniewska A., Kokot A., Jasnos M., Busiło S., (red.) M. Jasnos, Chcę pracować w Polsce, 2014, Warszawa.

Wróblewski B., 1948, Język prawny i prawniczy, Kraków.

Wüster E., 1979, Einführung in die Allgemeine Terminologielehre und terminologische Lexikografie, Wien-New York.

Zieliński M., 2004, Język prawny, język administracyjny, język urzędowy, w: Język-prawo - społeczeństwo, E. Malinowska (red.), Opole.

\section{Samanta Busito}

\section{ADMINISTRATIVE AND LAW LANGUAGE CHALLENGES FOR IMMIGRANTS}

Keywords: Polish for foreigners, migrant language education, language education of adult migrants

Summary. The article presents the creation of lexical inventories based on a reflective approach to teaching programs. Consistent application of the principle of meeting the communicative needs and "real-life" language tasks results in the introduction of specialized vocabulary in the field of law and public administration to the inventories at the A2 level, both in the area of public, as well as private life. An immigrant or a refugee has active and passive contact with specialized vocabulary in discussions/conversations with civil servants, staff of educational institutions, but also those Poles with whom s/he maintains unofficial or private contact. 